\title{
The scale of mission-embeddedness as a nonprofit revenue classification tool: Different earned revenue types, different performance effects
}

Jamie Levine Daniel ${ }^{1}$, Indiana University-Purdue University Indianapolis Mirae Kim, University of Missouri-Columbia

\begin{abstract}
Nonprofits rely on earned revenue to remain sustainable. Prior studies have generally aggregated all earned revenue and evaluated its influence on financial sustainability. Our study takes a different approach, assessing the effects of three different types of earned revenue on an immediate program outcome. We use Cultural Data Project data from 2,000 arts and culture nonprofits from 2004-2012. We find that embedded and integrated earned revenue are linked to better program outcomes while external earned revenue is related to poorer program outcomes. Results depend on type (performing v. visual arts) and funding structure (donative v. commercial).
\end{abstract}

\section{Citation:}

This is the author's accepted manuscript. The published version is available from:

Levine Daniel, J., \& Kim, M. (2018). The scale of mission-embeddedness as a nonprofit revenue classification tool: Different earned revenue types, different performance effects. Administration \& Society, 50(7), 947-972. https://doi.org/10.1177/0095399716647152

\footnotetext{
${ }^{1}$ Corresponding author: jlevined@iupui.edu
} 


\section{INTRODUCTION}

Nonprofit organizations face increasing financial challenges, and thus are showing growing interest in generating earned revenue (Dees, 1998; Salamon, 2012; Young, Salamon, \& Grinsfelder, 2012). In recent years, the number of nonprofits has greatly increased even though the proportion of income from charitable giving has remained nearly flat at $2 \%$ for a few decades (Pettijohn, 2014; Perry, 2013). In addition, for-profit enterprises have been encroaching on the domain where nonprofit activities have traditionally been dominant (Grønbjerg, 2001; Salamon, 2012). For nonprofit organizations, donative funds have become more difficult to secure, and private giving represent only $12 \%$ of total revenues for the nonprofit sector in general (Pettijohn, 2014). With competition so fierce, changes in giving can occur for various reasons that are not necessarily related to the performance of the recipient nonprofit organizations (Froelich, 1999; Hager, 2001). Consequently, more and more nonprofits seek to expand earned revenue as a way to diversify the revenue streams and to increase control over resources and decision-making related to the programs. Nonprofit organizations generate earned revenue through various kinds of activities. Some are closely related to their mission, while others are relatively distant to the main programs that align with their missions. Current nonprofit scholarship has paid limited attention to the different types of earned revenue and the various effects each type has on the organizations.

A number of empirical studies have argued that diversifying revenue streams, especially by expanding earned revenue sources, may help reduce financial vulnerability, therefore making nonprofit organizations more sustainable (Chang \& Tuckman, 1996; Carroll \& Stater, 2009; Greenlee \& Trussel, 2000; Froelich, 1999). Earned revenue takes many forms, including direct sales of a good, fees for services directly related to organizational mission, or income generated 
from for-profit goods or services ancillary to core activities. In the nonprofit sector, marketdriven earned revenue now accounts for over half of total funding (Young, Salamon, \& Grinsfelder, 2012; Pettijohn 2014).

Some scholars caution that nonprofits' revenue generating activities may go too far at the expense of fulfilling their mission (Eikenberry \& Kluver, 2004; Foster \& Bradach, 2005; Weisbrod, 2004). During the course of income-generating activities, too many resources can be spent on programs that are not closely aligned with the organization's core mission or do not contribute to the organization's achievement of its intended social impact. Revenue-generating initiatives may also create deficits and drain the agency's valuable resources that otherwise could be spent on core programs.

The empirical evidence on the effect of nonprofit commercial activities is mixed; commercial activities strengthen financial health, but can also compromise the focus of the organizations (Froelich, 1999; Hughes \& Luksetich, 2004; Sloan, 1998). These mixed results are likely due to the fact previous studies did not specify the nature of earned revenue. Previous studies tend to treat all types of earned revenues identically. One of the reasons can be attributed to the way relevant information is available from the IRS 990 forms, the most common source of information about nonprofit revenues (Child, 2010; Okten \& Weisbrod, 2000).

In this study, we categorize nonprofits' earned revenue in three ways to explore how different types of earned income affect a nonprofit organization's capacity to deliver on its missions, i.e.: whether each type of earned revenue serves as a complement, supplement, or even distraction to the delivery of its core programs. Based on Alter's (2004) conceptual framework, we categorize earned revenue activities as embedded, integrated, or external to the organization. To obtain more detailed information on the type of earned income, we rely on the data obtained 
from the Cultural Data Project (CDP) to capture various types of revenues. The use of the CDP data allows this study to be the first of its kind to distinguish between different types of earned revenue and empirically evaluate their effects on various aspects of nonprofit performance. This focus on nonprofit program-based outcomes rather than financial outcomes was previously not feasible with the IRS 990 data.

We chose to focus on nonprofit arts and culture organizations. The variation in organization type, size, and structure in the nonprofit sector make it difficult to generate analytic results for the entire sector at once. Even with the variation in a given subsector, focusing on one area improves the reliability of the results. The nonprofit arts sector as a whole generally receives slightly less than half of its revenue from contributed sources, and the rest come from commercial activities and investment (Americans for the Arts, 2013; Hall, 2010). For museums, art galleries, theaters, operas, orchestras, and dance companies, ticket sales have been the main source of income (Toepler \& Wyszomirski, 2012). In response to the changing environment and constant financial challenges, an increasing number of arts organizations have added new commercial activities, such as operating a gift shop, bookstore, or restaurant; renting out facilities; selling advertising in its program books or newsletter; and licensing its mailing list or brand.

The growing competition and changing funding environment put pressure on many nonprofits to actively seek new income-generating initiative that may or may not be related or to their core mission. These new income-generating activities however require strategies, management, and resources that could be different from the ones required to serve mission-based programs. More importantly, the extent to which these activities help organizations fulfill their missions may vary widely. In this study, we characterize each category of revenue generating 
activity in terms of its proximity to mission achievement and then analyze the influence each type makes on one aspect of nonprofit performance.

In the following section, we sort the types of earned revenue activities in which nonprofits engage into three categories: embedded, integrated, and external. We then hypothesize the relationships between each of these earned income activities and one measure of an immediate program outcome. We then introduce the dataset from the Cultural Data Project (CDP) used in our analyses. After we explore how each type of earned revenue is related to nonprofit performance for the whole sample, we provide sub-analyses for performing arts and visual arts organizations. We further analyze these sub-groups based on funding structure. We conclude this paper with a discussion of how nonprofit organizations can better design their commercial activities to remain mission-oriented while ensuring their financial sustainability.

\section{THEORETICAL BACKGROUND}

Nonprofit scholars have continuously advocated diversifying revenue streams as a way to spread out fiscal risk (Chang \& Tuckman, 1996; Froelich, 1999; Frumkin \& Keating, 2011; Jegers 1997; Kingma, 1993) and contribute to organizational stability in the form of financial capacity (Chikoto \& Neely 2014, Gras \& Mendoza-Abarca 2014). The advocates of revenue diversification strategy call for increased revenue generating activities. Expanding the share of earned revenue allows nonprofit organizations that have traditionally relied on donated income to diversify or expand their base in order to sustain their operation and meet growing needs with more flexibility.

Current research findings are, however, inconsistent or vague with regard to the effect of commercial activities on nonprofit performance. For example, Froelich (1999) theorizes that increasing earned revenue can help a nonprofit become more financially viable, while Sloan 
(1998) finds that hospitals that increase commercial activities often do so at the cost of their public service mission; that is, serving patients with limited financial capacity. In contrast, Hughes and Luksetich's (2004) study found no relationship between expanding commercial activities and the amount spent on program services. There seems to be no clear consensus as to whether increasing commercial revenue contributes to or deters from mission fulfillment, or whether all earned revenue effects organizations in the same ways.

There is limited discussion on how different types of earned revenue influence nonprofits, especially relating to their program outcomes. Typically, earned or commercial revenue has been studied as an aggregate sum of all income streams that are not contributed or derived from investment (Gilbert, 1985; Salamon, 1993; Dees, 1998; Young \& Salamon, 2002) or donations/contributions. Early studies (Segal and Weisbrod, 1998; Anheier \& Toepler, 1998) attempted to classify revenue activities as program service revenue versus revenue that is eligible for the IRS's unrelated business income tax.

However, not all earned revenue, or even program service revenue specifically, may contribute to nonprofit performance in a homogeneous way. Earlier theoretical studies offered conceptual measures to acknowledge this, such as James' (1983) discussion of profit and utility, and Weisbrod's (1998) classification of preferred collective, preferred private, and nonpreferred private goods. Oster (1995) attempts to link revenue activities to mission with a matrix whose dimensions include commitment to mission and commitment to economic vitality. Similarly, Frumkin and Andre-Clark (2000) classify organizations along dimensions of commitment to values (nonprofit as service delivery vehicle) and commitment to performance (nonprofits as producers of expressive outputs). Our study attempts to further disaggregate revenue generating activities and examine each activity vis-à-vis its connection to the organization's core mission. 
We apply two criteria to classify revenue generating activities based on each activity's relative embeddedness within the organization. To be more specific, our classification is based on Alter's (2004) framework and compares the earned revenue activity's business/program integration through organizational technology and target market to the organization's mission orientation. Organizational technology refers to financial resources; human resources, such as managerial expertise; and technology systems, such as production capacity (Damnpour \& Evan, 1984; Lovelock, 2004; Scott, 1975). These components support the primary work activities of an organization (Kimberly \& Evanisko, 1981).

To analyze nonprofit program outcomes, we use the size of annual attendance at arts organizations - the number of people served by organizations in a given year - as an immediate program outcome, per The Urban Institute's (n.d.) Outcome Indicator Project, which suggests the attendance as an appropriate immediate program outcome for performing arts organizations. The rationale is that the ultimate outcomes of arts organizations such as increased appreciation for the arts, enriched life experience, or increased social bonds in community can be achieved only when people come to attend at arts organizations' offerings. Therefore, our analysis uses the size of attendance to visualize arts organizations' immediate outcomes. We acknowledge that arts and culture organizations vary in their missions and desired program outcomes, and having larger attendance is often not a primary goal for many organizations. To a varying degree, arts organizations are committed to facilitating creative art works, bringing new forms of arts to the community, supporting local artists, providing arts education, and many other purposes. Still, attendance measures reflect general public commitment and the organizations' connections to the larger community (Zolberg, 1984), and follows other studies seeking to link commercial orientations to similar program outcomes (Voss \& Voss, 2000; White \& Simas, 2008) 
By connecting the dimensions of the earned revenue activities to organizational performance, we attempt to create a dynamic model in the spirit of Krug and Weinberg (2004), who examine whether the organization is doing the right things (mission), whether it is doing the right things financially (money), and quality or how well the program in question performs (merit). By looking at all three dimensions, their model helps managers strategically consider the multidimensional tradeoffs inherent in the pursuit of earned revenue. Similarly, we attempt to connect how an organization earns money to some aspect of outcome measurement in terms of mission achievement. In sum, our study assesses the impact three types of earned revenueembedded, external, and integrated - have on an immediate program outcome.

We regard the income an organization earns from its mission-based core programs as embedded revenue. Organizations earn embedded revenue while fulfilling core missions. Thus embedded revenue activities consume the resources budgeted for core missions. Also, embedded revenue activities target the same market their mission-driven programs aim to reach (Alter, 2004; Cooney, 2006). A typical example is selling admission tickets for a symphony orchestra concert. When audience members buy the ticket to enjoy symphony music, orchestras can achieve their mission to promote the appreciation of classical music in the community. Simultaneously, these orchestras bring in ticket sale revenue to the organization. Activities generating embedded revenue are considered preferred private goods/services according to Weisbrod (1998), and they contribute to both the mission and economic vitality of the organization (Oster, 1995). These activities show a strong tie between social legitimacy (mission) and financial balance, two of Krug and Weinberg's (2004) dimensions, and create opportunities for cost complementarities (Yetman 2003). Therefore, we can expect an increase 
in embedded revenue to be associated with better performance outcomes. This leads to the following hypothesis:

H1: An increase in the share of embedded revenue will be associated with an increase in immediate program outcomes.

In contrast to embedded revenue, there are earnings that are completely external to core mission activities. Such external earned revenue activities usually target different markets and use organizational technologies that are not shared with core activities. In Weisbrod's (1998) terms, these activities would be non-preferred goods. Using Oster's (1995) language, they may contribute to the organization's economic vitality but may not be connected to the mission. For example, symphony orchestras could offer a valet service. This is an external activity because the staff members doing the parking are not the musicians playing in the orchestra. Further, the people who benefit from parking facilities can be different from those attending the arts programs, or may never be exposed to the organization's core activities (e.g., a customer who uses the valet service because of its proximity to other attractions, and who never attends the symphony's performance). Non-mission-based commercial activities could be detrimental to nonprofit core mission activities because they potentially divert the organization's attention and/or draw additional resources away from core activities. In contrast to embedded income, external activities do not overlap with mission-based programs in terms of organizational technology and target markets, and may not help the organization realize end outcomes such as education or appreciation (in the case of an arts organization). External revenue may serve as a substitute for the organization's service-related activities, rather than a complement. In their study of the effects sponsorship and subsidies, Coates, et al. (2014) link these types of external funding to financial and volunteer problems. Krug and Weinberg (2004) may argue that this type 
of activity addresses the financial dimension, but not the mission dimension. This lack of overlap is expected to hurt the performance dimension. Therefore, we expect to find a negative relationship between external earned revenue and program outcomes:

H2: An increase in the share of external revenue will be associated with a decrease in immediate program outcomes.

Lastly, there is the question of integrated revenue, which occurs when nonprofit organizations integrate commercial- and mission-based activities on either the organizational technology or target market dimension, but not both. This type of revenue would be considered as preferred private in Weisbrod's (1998) parlance. Sometimes, nonprofit organizational core technologies can be utilized to produce new commercial activities (Gonzalez et al., 2002). For instance, a symphony can license its music to other outlets in order to reach new audiences. Or, organizations can leverage their current market relationships to deliver new services and see positive outcomes. The same symphony can use new technologies to record podcasts about its music and solicit subscriptions for this behind-the-scenes material. This activity may not directly contribute to its stated mission or immediate program outcomes, but can be useful to generate self-sustainable income without incurring a substantial amount of additional cost. It could also attract new audiences to its live performances. Such income streams are what constitute the sum of integrated revenue. Creating integrated streams may also be a means for an organization to achieve longer-term outcomes outcomes such as education or art appreciation.

However, negative outcomes from these revenue strategies are also possible. Previous research (AUTHOR, 20XX) demonstrates that nonprofits may degrade service delivery when they use existing organizational technologies to serve different target markets. Similarly, 
pursuing new audiences (i.e.: through podcasts) could come at the cost of immediate program outcomes by reducing time available for live performances.

Stakeholder theory may shed some light on the relationship between integrated revenue and organizational performance. This theory argues that organizations need to address stakeholder interests in order to be sustainable (Freeman 1984; Fassin 2009). Some integrated revenue activities target new markets, i.e., new stakeholders. Given that organizations have limited resources and capacity, nonprofit managers may not be able to give full attention to their main stakeholders (i.e., donors and core service recipients/consumers) or make the most use of available resources for mission-driven activities. Since a reasonable argument can be made in either direction, we hope this study will shed light on the relationship between integrated revenue and immediate program outcomes

\section{METHODOLOGY}

\section{Data}

The data for this analysis comes from the Cultural Data Project (CDP), which includes of data profiles collected from arts and culture organizations across twelve states (Kim \& Grizzle, 2016). Each profile contains financial, operational, and program data from a single fiscal year, as well as a board-approved audit or year-end financial statement. In this study, we use a sample that includes nearly 4,000 organizations with data profiles for each year between 2004 and 2012 . Although the CDP data has been collected since 2004, the number of years observed for each organization varies because the organizations joined in different years as the CDP expanded.

We run empirical estimations separately for visual arts organizations and performing arts organizations given that the way these two types of organizations serve attendees widely differ. 
We also run further sub-analyses for commercial nonprofits and for donative nonprofits to explore whether the different types of earned income have different effects based on funding structure. Hansmann (1980) classified nonprofits as donative or commercial based on whether the primary source of income is contributed or earned. We define commercial organizations to be those organizations that generate more than $50 \%$ of total revenue from earned income that does not include investment income. Donative organizations generate more than $50 \%$ of total revenue from contributions.

The CDP data covers a wide variety of arts organizations but not limited to art museums, history museums, natural science museums, performing arts centers, dance troupes, ballet companies, theater companies, symphony orchestras, operas, choral groups, and ensembles, which comprise the majority of the observations. The CDP also includes organizations that serve the arts industry including but not limited to alliances of arts organizations, professional society for artists, research institutes, ethnic awareness group, community celebrations, film and video, radio, arts education institutions, and historical preservation sites. We limit our observations to the organizations that directly serve the general public. Table 1 describes the type of organizations covered in our analysis, and Table 2 provides descriptive statistics separately for performing and visual arts organizations. We further divide these two groups into donative versus commercial nonprofits.

[Table 1]

\section{Dependent Variable: Immediate Program Outcomes}

In our study, we measure the size of total attendance at arts organizations in a given year as one immediate program outcome. This is a means of tailoring performance expectations for 
organizations whose primary mission is to attract individuals to see shows, art exhibits, and other culturally-related products. We view attendance to be a precursor to the realization of other cultural missions such as promoting appreciation for the arts or cultivating social cohesion. We measure total attendance in natural logarithm terms in order to make comparative assessments of variations among a large number of organizations. As shown in Table 2, the average total attendance size of performing arts organizations is much smaller $(74,478)$ than that of visual arts organizations $(186,224)$, and it is not surprising given that there are more flexibilities in the way visual arts organizations could serve individuals. Performing arts organizations can serve individuals only at given times and the number of people they can cater to at one time is often limited.

[Table 2]

\section{Independent Variables:}

Our data includes 19 different types of earned revenue, which we have sorted into three categories: embedded revenue, integrated revenue, and external revenue. The categorizations were made based on general assumptions about the relationship between the earned revenue activity and the organization as it relates to organizational technology and target market. We made these categorizations based on key language from the CDP data set. Table 3 includes descriptions and decision rules for the embedded, external, and integrated classifications.

[Table 3] 
Proportion of Embedded Revenue represents the sum of income from all activities that are embedded within core mission activities through both organizational technology and target markets, divided by total revenue (including all earned revenue as well as investment income and contributions). This variable includes admissions, ticket sales, performance subscriptions, membership dues, workshops, tuition, and touring income. Of the three types of earned revenue, embedded revenue represents the largest share across different types of organizations. It is interesting that the size of embedded revenue in performing arts (32\%) is nearly two times of that in visual arts (17\%). For both performing and visual arts, we see the average share of embedded revenue is much larger in commercial nonprofits than in donative nonprofits, suggesting that its influence on program outcomes would also differ.

Proportion of Integrated Revenue represents the sum of income from all activities that are embedded with core mission activities on one dimension - either organizational technology or target market - but not both. This sum is then divided by total revenue. These activities include contracted performances, gallery sales, media subscriptions, and royalties. Integrated revenue accounts for $4 \%$ in the subset of both performing arts nonprofits and visual arts nonprofits.

Proportion of External Revenue represents the sum of income from all activities that are external to core mission activities, divided by total revenue. Recall that these activities are considered external because they do not use the same organizational technology as the core mission activities, or the target the same markets. This variable includes concessions, parking, rent, advertising, sponsorship, special events, and other earned revenue (i.e., earned revenue not otherwise included in previously mentioned categories). The average proportion of external revenue is larger (10\%) in visual arts nonprofits and is smaller in performing arts nonprofits 
(6\%). This reflects that visual arts organizations seem to generate more revenue from activities such as special events or running a cafeteria that may not contribute to the mission directly but support the organizations, especially since people may avail themselves of conveniences offered through external activities (e.g.: a cafeteria) when spending an undetermined amount of time at a museum, compared to the finite performance slot of a performing arts offering.

\section{Control Variables}

More than 20 years ago, Chang and Tuckman (1991) made the first attempt to identify factors relevant to the financial vulnerability, inversely stability of nonprofit organizations, which is critical for successful performance. In their initial estimation, they adopted four criteria: equity balances, revenue concentration, administrative cost ratio, and operating margins. Subsequent studies have continuously used these indicators to measure financial sustainability, or inversely, financial vulnerability (Carroll \& Stater, 2009; Greenlee \& Trussel, 2000; Hager, 2001; Trussel \& Greenlee, 2004). The previous studies have shown that financially sustainable organizations have more diversified revenue streams, larger equity balances, greater operating margins, and larger administrative cost ratios. Thus, we control for these four factors in our econometric model to make sure that we look at the effect of each earned revenue types regardless of 1) the extent organizations diversify their revenue streams coming from donated, earned, and invested sources, 2) the extent they are leveraged by debts, 3) the level of profitability, and 4) their overall overhead expenses that could be redirected to the program if necessary.

Following prior studies, we measure Revenue Concentration using the HerfindahlHirschman Index (HHI). The HHI approach assigns a score ranging from 0 to 1 based on how 
evenly balanced an organization's revenue is among selected categories, where a larger value indicates a greater level of revenue concentration. In this study, we follow the approach of Carroll \& Stater (2009) and Frumkin \& Keating (2011) and measure revenue concentration using three revenue categories: earned income, investment income, and contributed income. To make the measurement interpretable, we set any negative revenues to $\$ 0$ (Hager, 2001). As shown in Table 2, organizations report a mean revenue concentration index of 0.6 , which suggests the revenue portfolios for the organizations in this sample are relatively concentrated. The average value of revenue concentration index does not show much difference across different groups of organizations.

The Non-Program Expense Ratio, the ratio of spending on non-program activities to total expenses, is another way to measure financial flexibility (Greenlee \& Trussel, 2000; Trussel, 2002; Tuckman \& Chang, 1991). During a fiscal crisis, nonprofits can shed nonprogram costs as way to protect their productivity. Thus, a higher percent of expenses spent on supporting tasks, which are not directly related to programs but are important to support program services, means an organization has more financial flexibility during challenging times. Since many organizations report fundraising efforts as a part of general management, we measure administrative costs as the sum of general management expenses and fundraising costs. The average value of this ratio is 0.26 for performing arts organizations. This means that, on average, a quarter of the sampled organizations' total expenses are attributed to administration and fundraising activities. The non-program expense ratio is slightly larger for visual arts organizations $(0.33)$.

Operating Margin measures the ability of a nonprofit to save or invest. It is calculated by subtracting total expenses from total revenues, and then dividing by total revenues. This ratio 
indicates the proportion of net income out of a nonprofit's total revenue that the organization can draw on in the event of fiscal shocks. Nonprofits with relatively low operating margins can be financially more vulnerable; they are more likely to cut programs and reduce human resources during financial distress (Greenlee \& Trussel, 2000; Hager, 2001; Trussel, 2002; Tuckman \& Chang, 1991). In our study, the full sample and subset samples all report low means (-0.02 for the performing arts group and -0.11 for the visual arts group). This low value indicates that organizations in our sample make virtually no surplus from their operations and run with very little margin to draw on in the event of crisis. It is noteworthy that commercial nonprofits operate with larger loss than the others for both performing and visual arts cases, suggesting that their commercial activities are likely to be driven by necessity to survive without sufficient government and charitable support.

Equity Ratio is calculated by dividing net assets by total revenues, and it estimates the organization's capacity to leverage its assets when the economy worsens. A nonprofit with a larger amount of equity balances can better weather financial setbacks (Greenlee \& Trussel, 2000; Trussel, 2002). Thus, we expect that organizations with a higher equity balance will be more likely to consistently operate their programs and maintain growth trends in program outcomes. The equity ratio is 0.08 for performing arts and 3.27 for visual arts organizations, demonstrating these organizations are generally able to handle setbacks, despite their low operating margins. In order to address the influence of outliers, operating margins was reset to a floor value of -25 and equity ratio was reset to a ceiling value of +25 , following Hager (2001).

Finally, we measure organization size through an organization's budget, more specifically by the natural logarithm of total expense. Controlling an organization's size constant helps our models accurately measure the impact of different shares of each revenue type on the 
outcome. In our study, performing arts nonprofit organizations report that they received an average of about $\$ 2.4$ million in a year during the period under analysis whereas visual arts organizations report the annual expense of $\$ 4.8$ million. We adjusted all values measured in dollar terms to 2013 values using the Consumer Price Index.

\section{Empirical Model}

To estimate the effects of various types of earned income on immediate program outcomes, we employ fixed effects model that allows us to capture the time-invariant heterogeneity within organizations. An arts organization's attendance in a given year is likely to

highly correlate with its previous year's attendance. While we still expect to see an incremental change in any given year, each organization would have a certain number of people that they expect to have every year given their reputation, size, location, and many others. We thus include a one-year lag of our dependent variable to capture such persistence over time. While employing such dynamic panel model accounts for the persistence in the dependent variable, the combination of fixed effects and lagged dependent variables introduces serious econometric bias; the lagged dependent variable is correlated with the organizational fixed effect and results in biased estimations. Such bias is more pronounced especially for large N, small T panel (Nickell, 1981), which is the case for our data.

Our study employs the Arellano-Bond (1991) dynamic panel data model to get around the problem of bias caused by the correlation between the lagged dependent variable and the error term. The Arellano-Bond (1991) estimator uses lagged values of the endogenous variables as instrumental variables after applying demeaning transformation to capture unobserved individual fixed effects. It is possible that revenue earned by selling admission tickets and 
attendance are simultaneously determined despite our hypothesis of earned revenue priorities set in one period affecting program outcomes in the next period. The use of lagged regressors as instruments helps address such potential endogeneity issues because predetermined lagged regressors are considered to be exogenous. The coefficient of the lagged dependent variable indicates the extent to which the attendance at arts nonprofits change during a year, and thus its positive value represents the general growth of attendance year over year. The use of ArellanoBond (1991) dynamic panel estimations allow us effectively control for the underlying attributes that determine the overall attendance level at each organizations, and focus on connecting the changes in attendance size to the ways organizations generate earned revenue. We report Windmeijer-corrected robust standard errors using Roodman's (2006) two-step Arellano-Bond estimator to address heteroskedasticity in our panel data.

Our empirical model is specified as follows:

$$
\begin{aligned}
& \text { Program Outcome }_{i t} \\
& \quad=b_{1} \text { Program Outcome }_{i t-1}+b_{2} \text { Embedded Revenue }_{i t}+b_{3} \text { Integrated Revenue }_{i t} \\
& \\
& +b_{4} \text { External Revenue }_{i t}+b_{5} \text { Revenue Concentration }_{i t} \\
& +b_{6} \text { Non_program_expense }_{i t}+b_{7} \text { Operating_margin }_{i t}+b_{8} \text { Equity }_{i t} \\
& +b_{9} \text { ln_Total expense }_{i t}+\alpha_{i}+\varepsilon_{i t}
\end{aligned}
$$

where Program Outcome represents total attendance, $\mathrm{i}=$ each organization in the sample, and $\mathrm{t}=$ the respective year for the organization between 2004-2012. We add year dummies to our empirical model as exogenous variables. It should be noted that the use of Arellano and Bond estimator is limited to the observations whose lagged values are available. Further, estimating the two-step difference GMM form of the model reduces an additional year of observations. Our final comprises 5,142 observations representing 2,093 nonprofit arts organizations for the period of 2004-2012. 


\section{Analytic Results}

To check for potential misspecification of the model, the Hansen test reports that overidentifying restrictions under the null hypothesis that the instruments used are exogenous. The Arellano-Bond statistic tests reveal statistically significant AR(1) errors, while the test statistic for $A R(2)$ errors remain statistically insignificant. These results all together indicate appropriate model specification. Finally, the Wald test results support that the joint significance of the coefficients.

According to Arellano-Bond estimations reported in Table 4, embedded and integrated earned revenue exhibit statistically significant and positive associations with total attendance over time. In other words, a greater share of earned revenue generated from main programs is associated with an increase in the number of people organizations served over time, as we expected. When the proportion of embedded revenue out of total revenue increases by $1 \%$, total attendance increases by $11 \%$ in performing arts organizations and by $28 \%$ in visual arts organizations. The share of integrated earned revenue shows a statistically significant result for performing arts only; a $1 \%$ increase in the share of integrated earned revenue out of total revenue leads to an average growth in total attendance of $17 \%$ over time. In Table 3 , we find no statistically significant relationship between external revenue and attendance for both performing and visual arts organizations.

[Table 4]

\section{Other Findings of Interest}


The regression results reveal that larger organizations, measured by the annual budget size, have larger audiences and more visitors coming to see their events or productions. The results also show performing arts organizations are likely to be more successful in serving greater attendees when they have larger operating margins than others. Although we did not find that nonprofit organizations have a tendency to experience persistent increases in their attendance over time, we believe controlling one-year lag of dependent variable allow the model to estimate the relationships between financial attributes and arts organizations' outcome (attendance in this case) free from the bias due to the correlations in attendance size from one period to another.

As stated above, we examine the relationship between revenue types and program outcomes separately for commercial nonprofits and for donative nonprofits because the influence of each type of earned revenue can vary, depending on the extent to which these organizations rely on earned revenue. The results reported in Table 5 support this view. Having a larger share of embedded revenue is linked to greater attendance for commercial type organizations in the subset of performing arts but for donative type organizations in the case of visual arts organizations. When the analysis is divided into sub-groups, we did not find a statistical evidence for integrated revenue. We however found a negative relationship for donative, performing arts organizations although the relationship is only marginally significant. Overall, the results in Table 5 suggest that the influence of varied types of earned revenue largely depends on the primary funding structure of these organizations.

[Table 5]

\section{DISCUSSION}


Nonprofit organizations pursue alternative strategies to expand earned revenue for many reasons such as to secure financial sustainability by diversifying revenue streams and to have more control over resources. However, balancing core, mission-based goals with commercial activities is delicate, especially if organizations want to ensure the latter without compromising the former. In the past, quantifying the programmatic outcomes of individual nonprofit organizations has been difficult, so studies have often relied on financial outcomes as proxies for a nonprofit's capacity. The main reason is a data shortage; there has not been enough data available that provides programmatic information for a large number of organizations. The CDP data, however, offers detailed information about program offerings. Using the CDP, we measure service outcomes in terms of annual, total attendance.

Considering the revenue activity's proximity to the organization's core mission-driven activity, as we have done in this paper, offers a means for organizations to determine the appropriate earned revenue activities for their portfolios. The concept of considering if and how revenue strategies are embedded also helps move the discussion beyond a sole focus on diversification in the portfolio, and instead toward a consideration of service level outcomes. In this paper, we found fairly strong evidence that a greater share of revenue coming from embedded type of earned income leads to the better program outcomes, represented in greater attendance. The estimated results are in line with the proponents of stakeholder theory who would expect a positive relationship between embedded revenue and organizational performance, since the target audiences for both are the same.

There are still a few other issues to consider. First, economies of scale may not be realized if the organization does not maintain adequate resources for all activities (Gray 2005). Second, targeting the same markets with multiple products could, in theory, lead to fatigue on the 
part of the client/customer. Barnes (2006) calls this "donor fatigue syndrome", an ongoing situation in which individuals are solicited by a plethora of organizations again and again (p.8). In the case of embedded revenue, members of the target market are clients and customers of the organization, and may also donate funds. Instead of coming from multiple organizations, this individual receives multiple requests from the same organization. A patron who donates to a symphony orchestra but who also must pay admission fees every time she attends concerts may grow tired of what she sees as constant requests, and may take her patronage elsewhere. Finding no significant coefficient of embedded revenue in the case of donative, performing arts organizations supports this point.

\section{CONCLUSION}

We categorized earned revenue into three types by its proximity to mission achievement, and we explored the relationship between different types of earned revenue and an immediate program outcome. Our analysis finds that arts organizations are likely to perform better and thus serve greater audiences when they generate larger shares of revenue from embedded and integrated sources of income, but they would perform poorly if the share of income generated from external type of commercial activities is larger. These results are not consistent when we divided arts organizations into four types: donative-performing arts, commercial-performing arts, donative-visual arts, and commercial-visual arts organizations, further demonstrating the importance of context and evaluating the connection between specific earned income activities and mission.

Previous empirical studies were limited and could not specify the effects various types of revenue make on nonprofit performance partly because they used an aggregate measure of 
revenue (or program service revenue). Our study contributes to the literature by introducing a framework that can be used to consider the finer-grained relationships between various types of earned revenue and nonprofit performance outcomes. Many of earlier studies looked only at financial outcomes and excluded other, performance-related outcomes. In this study we operationalize nonprofit organizations' performance in terms of how well programs are received by the public, that is, the total number of people attended the programs in a year.

Our analyses build on Weisbrod's (1998) preferred product matrix and Oster's (1995) product-portfolio matrix to offer nonprofit organizations ways to consider maximizing costcomplementarity. Our key findings enhance these theories by showing that it is necessary to disaggregate various types of earned revenue because not every earned income influences organizations in a homogenous manner. Additionally, our focus on immediate program outcomes helps determine whether earned revenue activities support or detract from core mission activities. Since nonprofit organizations presumably pursue earned revenue to support their mission, not just for portfolio stability, this link to organizational performance is essential. These findings have immediate, practical application. Nonprofit organizations looking to pursue earned revenue can use our framework to determine the right type of activity, taking into account their ultimate mission-driven goals.

This study is not without limitations, and these limitations must be taken into consideration when interpreting the results. We assume that the size of each revenue type does not reflect how many resources the organization spent on each type of revenue activities. Future studies should examine the amount of expenses associated with each type of revenue generating activities, although a challenge will be in how to identify those expenses. Another limitation is the representativeness of the sample covered in this study. The CDP does not cover the universe 
of nonprofit arts and cultural organizations, and the use of dynamic panel estimators that use lagged values as instruments eliminated observations without sufficient data. Still, the analytic results in this study provide valuable insight for future studies that intend to examine different nature of nonprofit commercial revenue activities and how they relate to program outcomes.

While a contribution in and of itself, the embeddedness typology does, itself, have limitations. The concept of integrated revenue acknowledges on an aggregate scale that an activity can be embedded within an organization on one dimension (e.g.: organizational technology) but external on the second (e.g.: target market). However, an activity that may be considered integrated for one organization may in fact be another organization's embedded revenue activity. Despite this limitation on an individual level, the framework allows for initial analysis of the connection between specific earned revenue activities and core mission-related programs.

Finally, current measure of program outcomes, attendance, may not fully capture the widely varying kinds of missions at arts and culture organizations. For some arts organizations, trying new initiatives or introducing unusual arts form may come at the expense of dropping attendance. Such artistic excellence may not be adequately captured by the overall attendance. Nonetheless, measuring attendance size across a large number of organizations should at least give us a starting point to analyze the link between growing earned income activities and program outcomes. Future studies should explore other measures that could capture multiple dimensions of artistically excellent program outcomes.

Despite these limitations, this study takes an important step forward because it highlights the need to distinguish various types of commercial activities and because it moves the discussion of earned revenue and service delivery beyond financial impacts, and toward different 
aspects of service delivery. Our approach offers a new means to evaluate earned revenue within

the context of an organization's mission-driven activities, and empirically demonstrates that

earned revenue has positive effects on program outcomes.

\section{Jamie Levine Daniel}

Dr. Levine Daniel is an assistant professor at the School of Public and Environmental Affairs and the Lilly Family School of Philanthropy at Indiana University-Purdue University Indianapolis. She earned her doctorate in public policy and management from Ohio State University's John Glenn College of Public Affairs. Her research interests include nonprofit enterprise, nonprofit management, capacity, organizational behavior, and organizational identity. Her dissertation, "Mission-Based Objectives, Market-Based Funding: The Relationship between Earned Revenue and Charitable Mission" (Stephanie Moulton, chair) considers the relationship between earned income and charitable mission, and to introduce a more robust measure of earned revenue that links to service-level outcomes. Her work has also been published as an e-case for the Hubert Project. As a doctoral student, she served as a research fellow for the Mid-Ohio Foodbank, and has been a fellow at ARNOVA and the Academy of Management conferences. She holds a BA from American University and an MBA from Ohio State University.

\section{Mirae Kim}

Dr. Kim is an assistant professor in the Truman School of Public Affairs at the University of Missouri. She came to the university in the fall 2014 semester after earning her doctorate in public administration from Rutgers University's School of Public Affairs and Administration. Her research interests include nonprofit financial management, the role of nonprofits in civil society, nonprofit arts management, and public-nonprofit partnerships. She is particularly interested in understanding how $501 \mathrm{c} 3$ nonprofit organizations balance their service and civic functions. Her articles have appeared in the Nonprofit and Voluntary Sector Quarterly, American Review of Public Administration, and Journal of Public Budgeting, Accounting \& Financial Management. During her doctoral years, she worked as a managing editor of Civic Engagement Magazine that seeks to deepen the discourse about, and underscore our shared commitment to, public service. She was also a member of the 2014 Penn Social Impact Doctoral Fellows Program under the direction of Dr. Peter Frumkin. She has a BA from Seoul National University and an MA from Carnegie Mellon University 


\section{REFERENCES}

Alter, K. (2004). Social enterprise typology. Virtue Ventures LLC.

AUTHOR. (20XX) details furnished post-review process

Americans for the Arts. (2013). Source of revenue for nonprofit arts organizations. Americans for the Arts.

Anheier, H. K., \& Toepler, S. (1998). Commerce and the muse: Are art museums becoming commercial? To Profit or Not To Profit: The Commercial Transformation of the Nonprofit Sector, 233-248.

Arellano, M., \& Bond, S. (1991). Some tests of specification for panel data: Monte Carlo evidence and an application to employment equations. The review of economic studies, 58(2), 277-297.

Barnes, M. (2006). Reducing donor fatigue syndrome. Nonprofit World, 24(2), 8-9.

Carroll, D. A., \& Stater, K. J. (2009). Revenue Diversification in nonprofit organizations: does it lead to financial stability? Journal of Public Administration Research and Theory, 19(4), 947-966.

Chang, C., \& Tuckman, H. (1996). Revenue diversification among nonprofits. Voluntas 5 (3): 273-90.

Chikoto, G. L., \& Neely, D. G. (2014). Building nonprofit financial capacity: The impact of revenue concentration and overhead costs. Nonprofit and Voluntary Sector Quarterly, 43(3), 570-588.

Child, C. (2010). Whither the turn? The ambiguous nature of nonprofits' commercial revenue. Social Forces, 89(1), 145-161.

Coates, D., Wicker, P., Feiler, S., \& Breuer, C. (2014). A bivariate probit examination of financial and volunteer problems of non-profit sport clubs. International Journal of Sport Finance, 9(3), 230-248.

Cooney, K. (2006). The institutional and technical structuring of nonprofit ventures: Case study of a US hybrid organization caught between two fields. Voluntas: International Journal of Voluntary and Nonprofit Organizations, 17(2), 137-155.

Damanpour, F., \& Evan, W. M. (1984). Organizational innovation and performance: the problem of "organizational lag". Administrative Science Quarterly, 392-409.

Dees, G. (1998). Enterprising Nonprofits. Harvard Business Review, 76(1), 54-61.

Eikenberry, A. \& Kluver, J. (2004). The Marketization of the Nonprofit Sector: Civil Society at Risk? Public Administration Review, 64(2), 132-140.

Fassin, Y. (2009). The stakeholder model refined. Journal of business ethics, 84(1), 113-13.

Foster, W., \& Bradach, J. (2005). Should nonprofit seek profits. Harvard business review, 83(2), 92-100.

Freeman, R. Edward. "The politics of stakeholder theory: Some future directions." Business ethics quarterly 4.04 (1994): 409-421.

Froelich, K. (1999). Diversification of revenue strategies: evolving resource dependence in nonprofit organizations. Nonprofit and Voluntary Sector Quarterly, 28(3), 246-268.

Frumkin, P., \& Andre-Clark, A. (2000). When missions, markets, and politics collide: Values and strategy in the nonprofit human services. Nonprofit and Voluntary Sector Quarterly, 29(suppl 1), 141-163. 
Frumkin, P., \& Keating, E. (2011). Diversification reconsidered: the risks and rewards of revenue concentration. Journal of Social Entrepreneurship, 2(2), 151-164.

Gilbert, N. (1985). The commercialization of social welfare. The Journal of Applied Behavioral Science, 21(4), 365-376.

Gonzalez, L. I. A., Vijande, M. L. S., \& Casielles, R. V. (2002). The market orientation concept in the private nonprofit organisation domain. International Journal of Nonprofit and Voluntary Sector Marketing, 7(1), 55-67.

Gras, D., \& Mendoza-Abarca, K. I. (2014). Risky business? The survival implications of exploiting commercial opportunities by nonprofits. Journal of Business Venturing, 29(3), 392-404.

Gary, M. S. (2005). Implementation strategy and performance outcomes in related diversification. Strategic Management Journal, 26(7), 643-664.

Grønbjerg, K. A. (2001). The US nonprofit human service sector: A creeping revolution. Nonprofit and Voluntary Sector Quarterly, 30(2), 276-297.

Greenlee, J., \& Trussel, J. (2000). Estimating the financial vulnerability of charitable organizations. Nonprofit Management and Leadership, 11(2), 199-210.

Hager, M. (2001). Financial vulnerability among arts organizations: A test of the TuckmanChang measures. Nonprofit and Voluntary Sector Quarterly, 30(2), 376-392.

Hall, P. (2010). Historical perspectives on nonprofit organizations in the United States. In R. D. Herman \& Associates (Eds), The Jossey-Bass handbook of nonprofit leadership and management, (pp. 3-41). San Francisco, CA: Jossey-Bass.

Hansmann, H. (1980). The role of nonprofit enterprises. Yale Law Journal, 89, 835-901.

Hughes, P., \& Luksetich, W. (2004). Nonprofit arts organizations: Do funding sources influence spending patterns? Nonprofit and Voluntary Sector Quarterly, 33(2), 203-220.

James, E. (2003). Commercialism and the mission of nonprofits. Society, 40(4), 29-35.

Jegers, M. (1997). Portfolio theory and nonprofit financial stability: A comment and extension. Nonprofit and Voluntary Sector Quarterly, 26(1), 65-72.

Kim, M. \& Grizzle, C. (2016). Assessing the strength and weakness of the Cultural Data Project: Measures in comparison with the NCCS 990 data. Journal of Public Budgeting, Accounting, and Financial Management, 28(3).

Kimberly, J. R., \& Evanisko, M. J. (1981). Organizational innovation: The influence of individual, organizational, and contextual factors on hospital adoption of technological and administrative innovations. Academy of management journal, 24(4), 689-713.

Kingma, B. (1993). Portfolio theory and nonprofit financial stability. Nonprofit and Voluntary Sector Quarterly, 22(2), 105-120.

Krug, K., \& Weinberg, C. B. (2004). Mission, money, and merit: Strategic decision making by nonprofit managers. Nonprofit Management and Leadership, 14(3), 325-342.

Lovelock, C. (2004).Targeting the market and developing a marketing plan. In S. M. Oster, C. W. Massarsky, \& S. L. Beinhacker (Eds.), Generating and sustaining nonprofit earned income: a guide to successful enterprise strategies (42-60). San Francisco: Jossey-Bass.

Nickell, S. (1981). Biases in dynamic models with fixed effects. Econometrica, 49, 1417-1426.

Okten, C., \& Weisbrod, B. A. (2000). Determinants of donations in private nonprofit markets. Journal of Public Economics, 75(2), 255-272.

Oster, S.M. (1995). Strategic Management for Nonprofit Organizations. Oxford Press. 
Perry, S. (2013). The Stubborn 2\% Giving Rate, The Chronicle of Philanthropy, retrieved from https://philanthropy.com/article/The-Stubborn-2-Giving-Rate/154691

Pettijohn, S. L. (2014). The Nonprofit Sector in Brief 2014: Public Charities, Giving and Volunteering.

Roodman, D. (2006). How to do xtabond2: An introduction to difference and system GMM in Stata (Working paper No. 103). Washington, DC: Center for Global Development.

Salamon, L. M. (1993). The marketization of welfare: Changing nonprofit and for-profit roles in the American welfare state. The Social Service Review, 16-39.

Salamon, L. (2012). The State of Nonprofit America, (2nd Edition). Washington, DC: Brookings Institution Press.

Scott, W. R. (1975). Organizational structure. Annual review of sociology, 1(1), 1-20.

Segal, L., \& Weisbrod, B. A. (1998). Interdependence of commercial and donative revenues. To Profit or Not to Profit: The Commercialization of the Nonprofit Sector, 105-127.

Sloan, F. A. (1998). Commercialism in nonprofit hospitals. To profit or not to profit: The commercial transformation of the nonprofit sector, 151-68.

Tinkelman, D., \& Neely, D. G. (2011). Research note: Some econometric issues in studying nonprofit revenue interactions using NCCS data. Nonprofit and Voluntary Sector Quarterly, 40(4), 751-761

Toepler, S. \& Wyszomirski, M. (2012). Arts and culture. In L. Salamon (Ed.), The state of nonprofit America (pp. 229-265). Washington, DC: Brookings Institute Press.

Trussel, J. (2002). Revisiting the prediction of financial vulnerability. Nonprofit Management and Leadership, 13(1), 17-31.

Trussel, J., \& Greenlee, J. (2004). A financial rating system for nonprofit organizations. Research in Government and Nonprofit Accounting. 11, 105-128.

Tuckman, H., \& Chang, C. (1991). A methodology for measuring the financial vulnerability charitable nonprofit organizations. Nonprofit and Voluntary Sector Quarterly, 20(4), $445-460$.

Urban Institute (n.d.). Outcome Indicators Project: A joint project of the Urban Institute and The Center for What Works. Washington, DC: Urban Institute.

Voss, G. B., \& Voss, Z. G. (2000). Strategic orientation and firm performance in an artistic environment. Journal of marketing, 64(1), 67-83.

Weisbrod, B. A. (1998). Modeling the nonprofit organization as a multiproduct firm: framework for choice. To profit or not to profit: The commercial transformation of the nonprofit sector, 47-64.

Weisbrod, B. A. (2004). The Pitfalls of Profits, Stanford Social Innovation Review, Volume 2, Number 3.

White, D. W., \& Simas, C. F. (2008). An empirical investigation of the link between market orientation and church performance. International Journal of Nonprofit \& Voluntary Sector Marketing, 13(2), 153-165.

Yetman, R. J. (2003). Nonprofit taxable activities, production complementarities, and joint cost allocations. National Tax Journal, 789-799.

Young, D. R. \& Salamon, L.M. (2002). “Commercialization, Social Ventures, and For-Profit Competition", in Lester M. Salamon (ed.), The State of Nonprofit America, Washington DC: Brookings Institution Press, pp.423-446 
Young, D. R., Salamon, L. M., \& Grinsfelder M. C. (2012). Commercialization, social ventures, and for-profit competition. The state of nonprofit America, 521-548.

Zolberg, V. L. (1984). American art museums: sanctuary or free-for-all?.Social Forces, 63(2), 377-392. 
Table 1. Organizations Types

\begin{tabular}{lllrr}
\hline Group & NTEE & Organization Type & Freq. & Percent \\
\hline & A40 & Visual Arts & 293 & 5.7 \\
& A50 & Museums & 165 & 3.21 \\
& A51 & Art Museums & 269 & 5.23 \\
Visual Arts & A52 & Children's Museums & 77 & 1.5 \\
& A54 & History Museums & 147 & 2.86 \\
& A56 & Natural History \& Natural Science & 22 & 0.43 \\
& A57 & Science \& Technology Museums & 35 & 0.68 \\
& A60 & Performing Arts & 252 & 4.9 \\
& A61 & Performing Arts Centers & 235 & 4.57 \\
& A62 & Dance & 463 & 9 \\
Performing & A63 & Ballet & 166 & 3.23 \\
Arts & A65 & Theater & 1,421 & 27.64 \\
& A69 & Music & 462 & 8.98 \\
& A6A & Opera & 464 & 9.02 \\
& A6B & Singing \& Choral Groups & 159 & 3.09 \\
& A6C & Bands \& Ensembles & 354 & 6.88 \\
& Total & 158 & 3.07 \\
& & 5,142 & 100 \\
\hline
\end{tabular}

Note: The National Taxonomy of Exempt Entities (NTEE) offers a definitive classification system for nonprofit organizations. 
Table 2. Descriptive Statistics

\begin{tabular}{|c|c|c|c|c|c|c|c|c|}
\hline \multirow{3}{*}{ Variables } & \multicolumn{4}{|c|}{ Performing Arts } & \multicolumn{4}{|c|}{ Visual Arts } \\
\hline & \multicolumn{2}{|c|}{ All } & \multicolumn{2}{|c|}{ Donative Commercial } & \multicolumn{2}{|c|}{ All } & \multirow{2}{*}{$\begin{array}{l}\text { Donative } \\
\text { Mean }\end{array}$} & \multirow{2}{*}{$\begin{array}{r}\text { Commercial } \\
\text { Mean }\end{array}$} \\
\hline & Mean & Std. Dev & Mean & Mean & Mean & Std. Dev & & \\
\hline Total Attendance & 80,206 & 806,984 & 74,478 & 59,023 & 186,224 & $1,570,447$ & 174,867 & 166,214 \\
\hline Proportion of Embedded Revenue & $32 \%$ & $22 \%$ & $20 \%$ & $50 \%$ & $17 \%$ & $16 \%$ & $11 \%$ & $35 \%$ \\
\hline Proportion of Integrated Revenue & $5 \%$ & $11 \%$ & $4 \%$ & $6 \%$ & $4 \%$ & $11 \%$ & $2 \%$ & $11 \%$ \\
\hline Proportion of External Revenue & $6 \%$ & $10 \%$ & $4 \%$ & $10 \%$ & $10 \%$ & $12 \%$ & $7 \%$ & $19 \%$ \\
\hline Revenue Concentration & 0.60 & 0.13 & 0.62 & 0.58 & 0.61 & 0.16 & 0.65 & 0.58 \\
\hline Non-Program Expense Ratio & 0.25 & 0.14 & 0.26 & 0.24 & 0.32 & 0.17 & 0.33 & 0.30 \\
\hline Operating Margin & -0.02 & 0.37 & -0.01 & -0.04 & -0.11 & 1.21 & -0.12 & -0.19 \\
\hline Equity Ratio & 0.80 & 1.59 & 0.74 & 0.78 & 3.27 & 4.05 & 3.32 & 2.07 \\
\hline Total Expense & $2,384,547$ & $10,400,000$ & $1,626,000$ & $2,640,292$ & $4,753,232$ & $19,300,000$ & $3,579,686$ & $5,885,373$ \\
\hline Sample Size & 4,134 & & 2,364 & 1,597 & 1,008 & & 663 & 236 \\
\hline
\end{tabular}


Table 3. Description of Earned Revenue Types

\begin{tabular}{|c|c|c|c|c|}
\hline Category & $\begin{array}{l}\text { Org. } \\
\text { Tech }\end{array}$ & $\begin{array}{l}\text { Target } \\
\text { Market }\end{array}$ & Revenue Stream & Key Language (from CDP) \\
\hline \multirow{7}{*}{$\begin{array}{l}\text { Embedded } \\
\text { Revenue }\end{array}$} & \multirow{7}{*}{$\begin{array}{l}\text { Always } \\
\text { the same } \\
\text { as core } \\
\text { mission } \\
\text { activities }\end{array}$} & \multirow{7}{*}{$\begin{array}{l}\text { Always the } \\
\text { same as } \\
\text { core } \\
\text { mission } \\
\text { activities }\end{array}$} & Admissions & Result of visitation \\
\hline & & & Tickets & $\begin{array}{l}\text { Result of } \\
\text { performance/presentation/exhibition }\end{array}$ \\
\hline & & & $\begin{array}{l}\text { Performance } \\
\text { subscriptions }\end{array}$ & Tied directly to ticket sales \\
\hline & & & Membership dues & Collection of dues/fees \\
\hline & & & Workshops & One-time events \\
\hline & & & Tuition & Ongoing series of classes/courses \\
\hline & & & Touring & $\begin{array}{l}\text { Performances away from home/usual } \\
\text { venue }\end{array}$ \\
\hline \multirow{4}{*}{$\begin{array}{l}\text { Integrated } \\
\text { Revenue }\end{array}$} & \multirow{4}{*}{$\begin{array}{l}\text { Depends } \\
\text { on core } \\
\text { mission } \\
\text { activities* }\end{array}$} & \multirow{4}{*}{$\begin{array}{l}\text { Depends } \\
\text { on core } \\
\text { mission } \\
\text { activities* }\end{array}$} & $\begin{array}{l}\text { Contracted } \\
\text { performances }\end{array}$ & Under contract to another organization \\
\hline & & & Gallery & $\begin{array}{l}\text { Sales in gallery/sales of self-produced } \\
\text { publications }\end{array}$ \\
\hline & & & Media subscriptions & $\begin{array}{l}\text { Sales of subscriptions for media } \\
\text { produced by org. }\end{array}$ \\
\hline & & & Royalties & Use of intellectual property \\
\hline \multirow{8}{*}{$\begin{array}{l}\text { External } \\
\text { Revenue }\end{array}$} & \multirow{8}{*}{$\begin{array}{l}\text { Different } \\
\text { from/not } \\
\text { tied to } \\
\text { core } \\
\text { mission } \\
\text { activities }\end{array}$} & \multirow{8}{*}{$\begin{array}{l}\text { Different } \\
\text { from/not } \\
\text { tied to core } \\
\text { mission } \\
\text { activities }\end{array}$} & Gift shop & All merchandise sales \\
\hline & & & Concessions & $\begin{array}{l}\text { Concession commissions as a result of } \\
\text { food sales }\end{array}$ \\
\hline & & & Parking & $\begin{array}{l}\text { Fees generated by lot or garage } \\
\text { owned/leased by org. }\end{array}$ \\
\hline & & & Rent & Renting out space for on-site events \\
\hline & & & Advertising & Sale of ad space \\
\hline & & & Sponsorship & $\begin{array}{l}\text { Revenue from corporations in } \\
\text { exchange for use of corporation } \\
\text { logo/promotions }\end{array}$ \\
\hline & & & Special events & $\begin{array}{l}\text { Events not held for fundraising, not } \\
\text { captured in workshops, etc. }\end{array}$ \\
\hline & & & $\begin{array}{l}\text { Other earned } \\
\text { revenue }\end{array}$ & Unspecified, open-ended \\
\hline
\end{tabular}

*One dimension is the same, one is different - depends on revenue activity 
Table 4. Dynamic Panel Estimation of Total Attendance/Visitor (In)

\begin{tabular}{lcccc}
\hline & \multicolumn{2}{c}{ Performing Arts } & \multicolumn{2}{c}{ Visual Arts } \\
\cline { 2 - 5 } & Coef. & $\begin{array}{c}\text { Windmeijer- } \\
\text { corrected robust } \\
\text { standard errors }\end{array}$ & Coef. & $\begin{array}{c}\text { Windmeijer- } \\
\text { corrected robust } \\
\text { standard errors }\end{array}$ \\
\hline $\begin{array}{l}\text { One-year lag of DV } \\
\text { Proportion of }\end{array}$ & 0.040 & $(0.104)$ & -0.062 & $(0.126)$ \\
$\quad$ Embedded Revenue & 0.011 & $(0.006)^{*}$ & 0.028 & $(0.008) * * *$ \\
$\quad$ Integrated Revenue & 0.017 & $(0.010)^{*}$ & -0.007 & $(0.010)$ \\
$\quad$ External Revenue & -0.005 & $(0.011)$ & -0.012 & $(0.009)$ \\
Controls & -0.563 & $(0.506)$ & -0.855 & $(0.529)$ \\
$\quad$ Revenue Concentration & -0.336 & $(0.318)$ & -0.628 & $(0.905)$ \\
$\quad$ Non-Program Expense Ratio & 0.277 & $(0.159) *$ & -0.026 & $(0.089)$ \\
$\quad$ Operating Margin & 0.063 & $(0.055)$ & -0.030 & $(0.034)$ \\
$\quad$ Equity Ratio & 0.545 & $(0.137) * * *$ & 0.861 & $(0.220) * * *$ \\
$\quad$ Total Expense(In) & & 81 & & 80 \\
Number of Instruments & & 4,134 & & 1,008 \\
Number of Observations & & 1,672 & & 421 \\
Number of Organizations & & 0.527 & 0.556 \\
Hansen test HO : Valid IVs & & 0.004 & 0.024 \\
Arellano-Bond statistic test AR1 & & 0.642 & 0.382 \\
Arellano-Bond statistic test AR2 & & 0.890 & 0.986 \\
Exogeneity of Instruments & & & &
\end{tabular}

Note: $* * *$ significant at .01, $* *$ significant at point $.05, *$ significant at .1 
Table 5. Sub-Analyses for Donative versus Commercial Nonprofits

\begin{tabular}{|c|c|c|c|c|}
\hline & \multicolumn{2}{|c|}{ Performing Arts } & \multicolumn{2}{|c|}{ Visual Arts } \\
\hline & \multirow{2}{*}{$\begin{array}{l}\text { Donative } \\
\text { Coef. }\end{array}$} & \multirow{2}{*}{$\begin{array}{l}\text { Commercial } \\
\text { Coef. }\end{array}$} & \multirow{2}{*}{$\begin{array}{l}\text { Donative } \\
\text { Coef. }\end{array}$} & \multirow{2}{*}{$\begin{array}{l}\text { Commercia } \\
\text { Coef. }\end{array}$} \\
\hline & & & & \\
\hline One-year lag of DV & 0.040 & $-0.252^{* *}$ & -0.046 & 0.118 \\
\hline \multicolumn{5}{|l|}{ Proportion of } \\
\hline Embedded Revenue & 0.006 & $0.009^{* *}$ & $0.053^{* *}$ & 0.011 \\
\hline Integrated Revenue & 0.002 & 0.010 & -0.006 & 0.019 \\
\hline External Revenue & -0.030 * & 0.000 & -0.021 & 0.002 \\
\hline \multicolumn{5}{|l|}{ Controls } \\
\hline Revenue Concentration & 0.119 & -0.481 & -0.702 & -1.941 \\
\hline Non-Program Expense Ratio & 0.292 & -0.272 & -0.024 & -1.018 \\
\hline Operating Margin & 0.091 & 0.246 & -0.085 & 0.001 \\
\hline Equity Ratio & 0.048 & 0.052 & -0.041 & -0.008 \\
\hline Total Expense(In) & 0.286 & $0.508^{* * *}$ & $1.234^{* * *}$ & 0.076 \\
\hline Number of Instruments & 74 & 79 & 74 & 64 \\
\hline Number of Observations & 2,364 & 1,597 & 663 & 236 \\
\hline Number of Organizations & 1,079 & 800 & 311 & 117 \\
\hline Hansen test HO : Valid IVs & 0.287 & 0.858 & 0.240 & 0.779 \\
\hline Arellano-Bond statistic test AR1 & 0.004 & 0.541 & 0.044 & 0.389 \\
\hline Arellano-Bond statistic test AR2 & 0.162 & 0.397 & 0.999 & 0.590 \\
\hline Exogeneity of Instruments & 0.477 & 0.569 & 0.686 & 0.608 \\
\hline
\end{tabular}

Note: Windmeijer-corrected robust standard errors are used. $* * *$ significant at $.01, * *$ significant at point $.05, *$ significant at .1 